\title{
Programs for children in military families
}

Mogil, Catherine; Heiselberg, Maj Hedegaard; Clement, Allison; Nielsen, Anni Brit Sternhagen

Published in:

Journal of Military, Veteran and Family Health

DOI:

10.3138/jmvfh.2019-0011

Publication date:

2019

Document version

Publisher's PDF, also known as Version of record

Document license:

Unspecified

Citation for published version (APA):

Mogil, C., Heiselberg, M. H., Clement, A., \& Nielsen, A. B. S. (2019). Programs for children in military families. Journal of Military, Veteran and Family Health, 5(Supplement 2), 97-115. https://doi.org/10.3138/jmvfh.20190011 


\title{
Programs for children in military families
}

\author{
Catherine Mogila, Maj Hedgegaard Heiselberg ${ }^{\mathrm{b}, \mathrm{c}}$, Allison Clement ${ }^{\mathrm{a}}$, and Anni Brit Sternhagen \\ Nielsen ${ }^{\mathrm{b}, \mathrm{d}}$
}

\begin{abstract}
Introduction: This article reviews representative programs for families and children from each NATO and Partnership for Peace (PfP) country with a representative participating in the NATO HFM RTG-258 task group on the impact of military life on children in military families. Methods: Each participating country was invited to submit up to three programs targeted at military-connected children and families. Results: 26 programs from nine countries were reviewed and categorized into 13 typologies. Discussion: The number of services offered in each country appeared to be influenced by size of the military, the degree to which military life is separate or immersed in civilian life, and the access to universal and preventive health care. Program descriptions for representative programs are included, as well as recommendations for program development, evaluation, and implementation.
\end{abstract}

Key words: military families, NATO, resources for children of military parents, support programs for military families, well-being of military children

\section{RÉSUMÉ}

Introduction : Le présent chapitre examine les programmes types pour les familles et les enfants de chaque pays de l'OTAN et du Partenariat pour la paix (PPP) qui avait un représentant au sein du groupe de travail Répercussions de la vie militaire sur les enfants de familles militaires. Méthodes : Chaque pays participant a été invité à soumettre jusquà trois programmes en lien avec les enfants et les familles militaires. Résultats et discussion: La quantité de services offerts par chaque pays semble être influencée par la taille de la force militaire, la proximité de la vie militaire par rapport à la vie civile, et l’accès à des soins de santé universels et préventifs. La description des programmes présentés par les participants est incluse, ainsi que des recommandations pour l'élaboration, l'évaluation et la mise en œuvre de programmes.

Mots-clés : familles militaires; OTAN, programmes de soutien aux familles militaires, bien-être des enfants militaires, ressources pour les enfants de parents militaires

\section{INTRODUCTION}

A growing body of research highlights the impact of parental military service on children. ${ }^{1}$ In general, children in military families are doing well, but current research suggests areas of specific risk tied to developmental periods, recency of parental deployment, and parent functioning may affect child mental health and academic functioning. ${ }^{1-3}$ The mental health and well-being of children in military families is supported by the fact that at least one parent is employed (by the military), which is a protective factor identified in child well-being research. ${ }^{4-6}$ In some countries, such as Canada, the United
Kingdom, and the United States, family support is bolstered by additional safeguards provided by the military service, like subsidized housing and childcare. ${ }^{7-11}$ In addition, the military ethos of strength, sacrifice, and being of service may support family resilience in countries with a strong and unique military culture. ${ }^{3}$ In the United States, for instance, it is commonly said that when one family member serves in the military, the entire family serves. ${ }^{1}$ In addition, considerable research suggests that families play a role in successful military deployment. ${ }^{12-16}$

Over the last 15 years, researchers have increasingly focused attention on developing programs to better meet

a Semel Institute for Neuroscience and Human Behavior, University of California, Los Angeles

b Danish Defence Personnel Organisation, Ringsted, Denmark

c Department of Anthropology, University of Copenhagen, Denmark

d Research Unit and Section of General Practice, Institute of Public Health, University of Copenhagen, Denmark

Correspondence should be addressed to Catherine Mogil at cmogil@mednet.ucla.edu 
the needs of children in military families by examining both risk and protective factors of child well-being. ${ }^{17-22}$ Recommendations centre on the need to study the effectiveness of programs for use with military populations and to ensure that existing programs are adapted to take into account the circumstances that are considered specific for military families. ${ }^{23}$ Many researchers also suggest using a family approach to treatment because parents may be more likely to seek support for their children than for themselves. ${ }^{1,24-26}$ There are a few evidence-based programs developed specifically for military families with children that target improved family communication, strengthening parent-child relationships, and

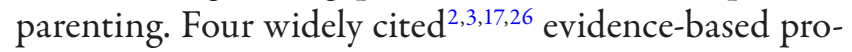
grams developed in the United States have been used for military families: After Deployment Adaptive Parenting (ADAPT), ${ }^{27}$ Families OverComing Under Stress (FOCUS), ${ }^{24}$ Passport Toward Success, ${ }^{28}$ and Strong Families Strong Forces. ${ }^{25}$ Of these four interventions, only FOCUS has been implemented in one other NATO or Partnership for Peace (PfP) country (Canada), though it has not been evaluated there. At the time this article was prepared (winter 2018), we could not identify any citations for evidence-based, family-level, and military-specific interventions with child outcome data in countries outside the United States, although there is an evaluation of child and adolescent support groups (that include a parent component) underway in Denmark.

We identified one example of a widely disseminated evidence-based intervention in several NATO and PfP countries, the Prevention and Relationship Education Program (PREP; formerly known as the Prevention and Relationship Enhancement Program). ${ }^{29}$ PREP has undergone randomized controlled trials (RCTs) in the United States and has been implemented in Denmark, Norway, and Sweden. A mixed-methods evaluation is underway in Denmark. However, PREP does not target the parent-child relationship directly; its primary focus is on improving the relationship between couples (i.e., in a military context).

To better understand the variety of services that may support the well-being of children in military families, this task group aimed to identify best practice programs for families and children that addressed the challenges of military life. We aimed to inspire NATO and PfP countries to learn from the experiences of countries that have already developed and evaluated programs because developing new programs is costly and may not always include evaluation of efficacy. Consequently, this article provides an overview of programs considered "best practice" in NATO and PfP countries, including type and purpose of program, target audience, theoretical foundation, and whether the program has undergone evaluation.

\section{METHODS}

Representatives of the NATO Human Factors Medicine Research Task Group-258 (HFM RTG-258) completed a survey about programs aimed at improving the lives of children in military families in their own country, which may include enhancing family dynamics or helping children adapt to changing military contexts. The representatives were asked to submit information to the authors of this article about as many as three programs that represented the types of services available to military families in their country, or programs that were considered innovative or particularly helpful to children of military families.

The task group representatives collectively determined that it would not be feasible to review more than three programs per country and that doing so might further weight the report toward programs developed in countries with larger military services (the United States, Canada, and the United Kingdom). The task group representatives were advised to prioritize programs that had a theoretical basis and that had demonstrated evidence for their effectiveness or had undergone some form of program evaluation (i.e., quantitative, qualitative, or mixed-methods) that included outcomes for children. If no such program (or less than three programs) met these criteria, task group representatives were invited to submit information about other existing military family programs.

Because the submission limit (three programs) suppressed the variety of program type from each country, we sent a secondary chart that listed the primary categories of identified services and asked the task group representatives to indicate whether their country had programs in one or more of the listed categories. The categorization of the submitted programs from each country was done by the authors of this article and was based on (1) country, (2) type of program, (3) target audience, and (4) information about whether the programs had a theoretical foundation and had undergone evaluation. The categorization was primarily done by the first author and discussed with the co-authors. In case of disagreement, a common solution was prioritized after a discussion. 


\section{RESULTS}

A total of 36 programs were submitted from 9 countries (Canada, Denmark, Estonia, Germany, Norway, Romania, Sweden, the United Kingdom, and the United States). However, some representatives submitted more than three programs and some only submitted one program. When more than three programs were submitted, the authors prioritized the three that had undergone program evaluation, bringing the total number of programs included in this report to 26.

Table 1 shows the 26 programs that were selected from the submitted programs. The programs were categorized by type: informational/educational resources/ support centres, financial support for education, financial support for material necessities or hobbies, family retreats, couples retreats, camps for children, family-level programs, couple-level programs, parenting classes, intervention/support groups for children and teenagers, online counselling, books for children, and wellness mobile apps. For example, seven of nine countries handed in information about programs that could be grouped under informal/educational resources/support centres and couple-level programs.

Table 2 shows the 13 typologies and which countries offer programs within each category, as reported by country representatives. As shown, evidence-based or widely disseminated programs were included in the list specifically (not just by category), namely PTSD Family Coach, FOCUS, ADAPT, and PREP.

Table 3 lists each of the programs, target audiences, evaluation methods, and references. Two programs have a randomized controlled effectiveness trial or comparison groups (ADAPT and FOCUS), eight have mixed-methods evaluations, three qualitative evaluations, and four have user satisfaction and feedback singularly (not as part of mixed-methods/qualitative methods).

\section{DISCUSSION}

This article provided an overview of NATO and PfP country programs with a focus of improving the lives of children in military families. Results of our survey of the task group members (details presented in the Table $\mathbf{1}$ through Table 3) illustrate the diverse range of programs across countries, including evidence-based and promising practices.

The importance of supporting child well-being in military families is a relatively new area of research that has received increasing attention over the last 15 years ${ }^{30}$ because of research suggesting that there are distinct factors that place children in military families at risk for psychological and behavioural disorders. A new tendency seems to be emerging among researchers, however, who have begun investigating military children's potential resources and strengths and the positive outcomes of a military lifestyle. ${ }^{31}$ To reduce the impact of specific risk factors, several programs have been developed to better support the well-being of children in military families. Each country with a participating task group representative offered at least one program that targets the needs of children, though often programs impacted the child indirectly through intervention with the parents (e.g., PREP, couple-level programs, financial support; see Table 2).

Our results identified variability not only in the number of available military-specific programs, but also in the types of programs offered across each of the NATO and PfP countries. We found that some countries had relatively fewer child- and family-focused military programs available, whereas countries such as Canada and the United States had many programs targeting military families, with a wider variety of service types. An important factor affecting the quantity as well as focus of the programs available in the countries represented in this report is the presence or absence of a state welfare system (see Chapter 5). Countries that offer state-funded health care often have a focus on universal, selective, or indicated prevention programming that may help to reduce the need for military-centric services. For example, in many of the Scandinavian countries, new parents and their infants may receive home visiting services to support the health and well-being of both the child and parents. ${ }^{32}$ Such services are not automatically available in other countries. In the United States, for example, home visiting services are only publicly funded for families that have a specific risk factor and qualify for public funding assistance, but are offered to military families as a specific military-centric program..$^{33}$ This is in contrast to Denmark and Sweden, for instance, where all families regardless of their military service involvement can receive home visiting services. ${ }^{34}$ In other words, support for military families is, in some countries, part of the national health care services provided for all families.

The availability of evidence-based programs submitted by representatives from the task group varied across countries (see Table 1 and Table 3). For the purpose of this article, we requested programs that had 


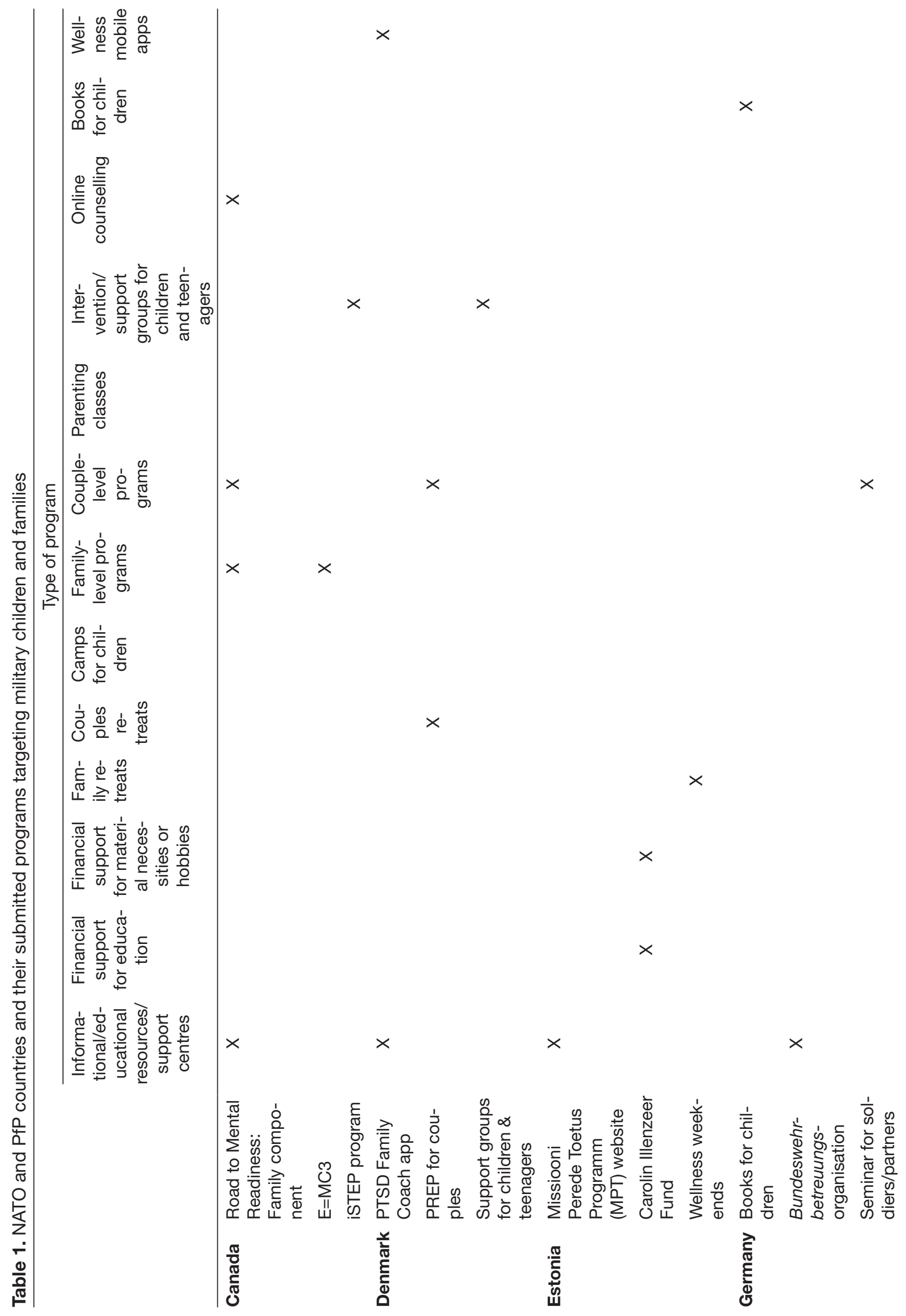




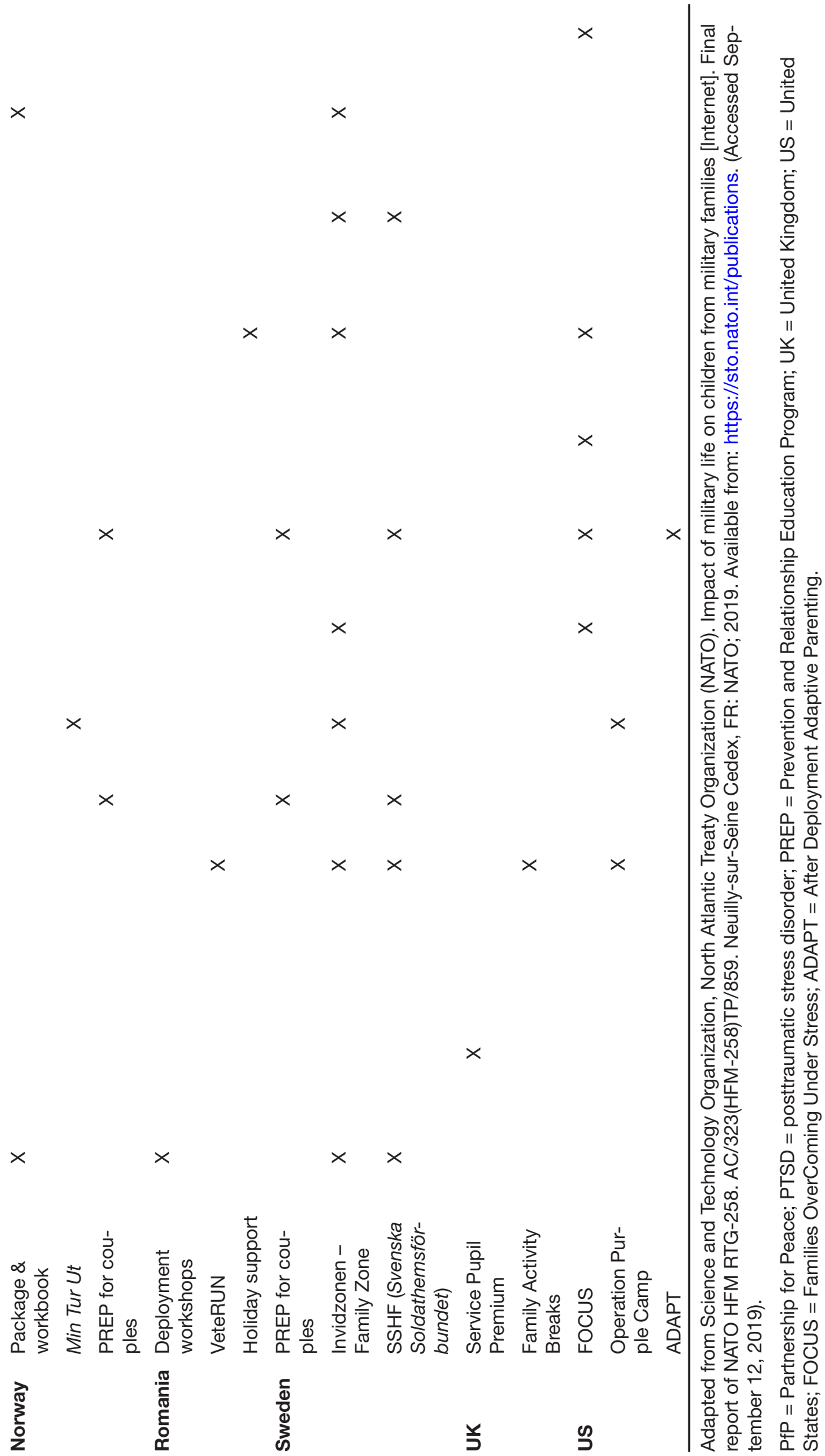


Table 2. Type of program targeting military children and families in NATO and PfP countries

\begin{tabular}{|c|c|c|c|c|c|c|c|c|c|}
\hline Type of program & Canada & Denmark & Estonia & Germany & Norway & Romania & Sweden & UK & US \\
\hline $\begin{array}{l}\text { Informational/educational } \\
\text { resources/support centres }\end{array}$ & $x$ & $x$ & $x$ & $x$ & $x$ & $x$ & $x$ & $x$ & $x$ \\
\hline Financial support for education & & & $x$ & & & & & $x$ & $x$ \\
\hline $\begin{array}{l}\text { Financial support for material } \\
\text { necessities or hobbies }\end{array}$ & & & $\mathrm{x}$ & & & & & & $\mathrm{x}$ \\
\hline Family retreats & & $x$ & $x$ & $x$ & & $x$ & & & $x$ \\
\hline Couples retreats & & $x$ & & $x$ & $x$ & & $x$ & & $x$ \\
\hline Camps for children & & & & $x$ & $x$ & & & $x$ & $x$ \\
\hline Family-level programs & $x$ & & & & & & $x$ & & $x$ \\
\hline Couple-level programs & $x$ & $\mathrm{x}$ & & $x$ & $x$ & & $x$ & & $x$ \\
\hline \multicolumn{10}{|l|}{ Parenting classes } \\
\hline $\begin{array}{l}\text { Intervention/support groups } \\
\text { for children and teenagers }\end{array}$ & $x$ & $x$ & & & & $x$ & $x$ & & $x$ \\
\hline Online counselling & & & & & & & $x$ & & $x$ \\
\hline Books for children & & $x$ & & $x$ & & & $x$ & & $x$ \\
\hline Wellness mobile apps & & $x$ & & & & & & & $x$ \\
\hline \multicolumn{10}{|l|}{ Legal Aid } \\
\hline FOCUS & $x$ & & & & & & & & $x$ \\
\hline PREP & & $x$ & & & $x$ & & $x$ & & $x$ \\
\hline \multicolumn{10}{|l|}{ ADAPT } \\
\hline PTSD Family Coach app & & $x$ & & $\mathrm{x}$ & & & & & $\mathrm{x}$ \\
\hline
\end{tabular}

Adapted from Science and Technology Organization, North Atlantic Treaty Organization (NATO). Impact of military life on children from military families [Internet]. Final report of NATO HFM RTG-258. AC/323(HFM-258)TP/859. Neuilly-sur-Seine Cedex, FR: NATO; 2019. Available from: https://sto.nato.int/publications. (Accessed September 12, 2019).

PfP = Partnership for Peace; UK = United Kingdom; US = United States; FOCUS = Families OverComing Under Stress; PREP $=$ Prevention and Relationship Education Program; ADAPT = After Deployment Adaptive Parenting; PTSD = posttraumatic stress disorder.

child-related outcomes, even if they only demonstrated feasibility or satisfaction. Most task group representatives were not able to put forth three such programs. One possible explanation for this could be the limited number of military-specific programs with research to support their efficacy. Evaluation is costly and some countries may have adapted programs that have already been evaluated in the country of origin (such as PREP).

It is important to note that we did not request programs that were implemented more broadly across the population if they were not also specifically adapted for use with military families. Adaptation is an important aspect of implementation because it is important to ensure that an intervention can appropriately meet the cultural context and specific needs of the target population. ${ }^{35}$ As a result, several of the submitted programs had been used in a more general (non-military) population with additional adaptation for military-specific challenges.
For example, Denmark's support groups for children and teenagers of parents with deployment-related mental health symptoms, such as PTSD, depression, or anxiety, were adapted from an evidence-based support group curriculum available to Danish children having a parent suffering from mental illness. ${ }^{36}$ In order to ensure that the intervention was responsive to the needs of the military community, it was important to augment the population-based program for use in military families to account for the additional challenges that can come from repeated or extended separations from a primary caregiver, parental risk, and other challenges associated with parental deployment and combat-related injuries. The military-specific adaptation is currently being evaluated.

It is important to note, however, that programs not specifically targeted at military families may be efficient and successful among service personnel and their family 


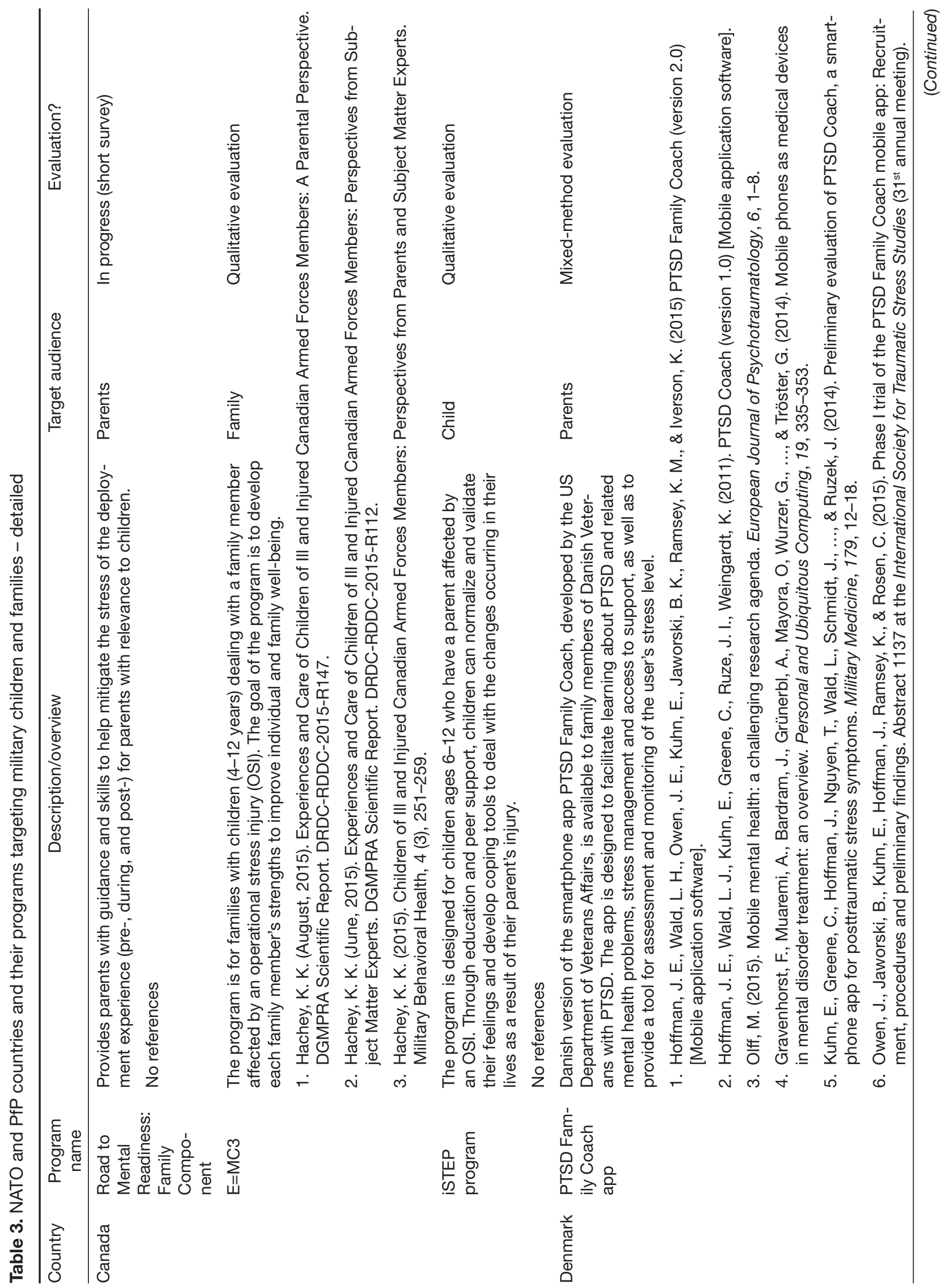




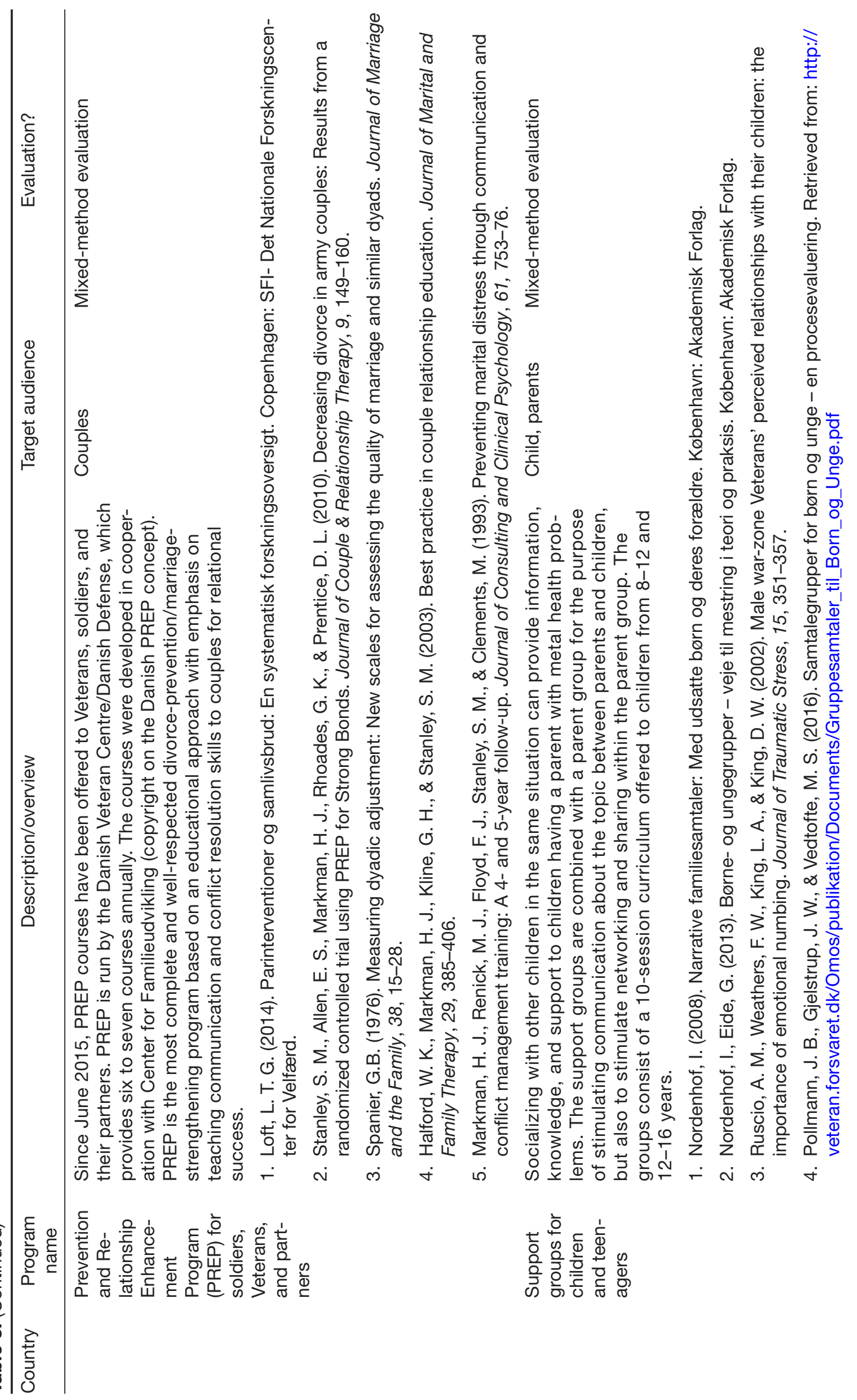




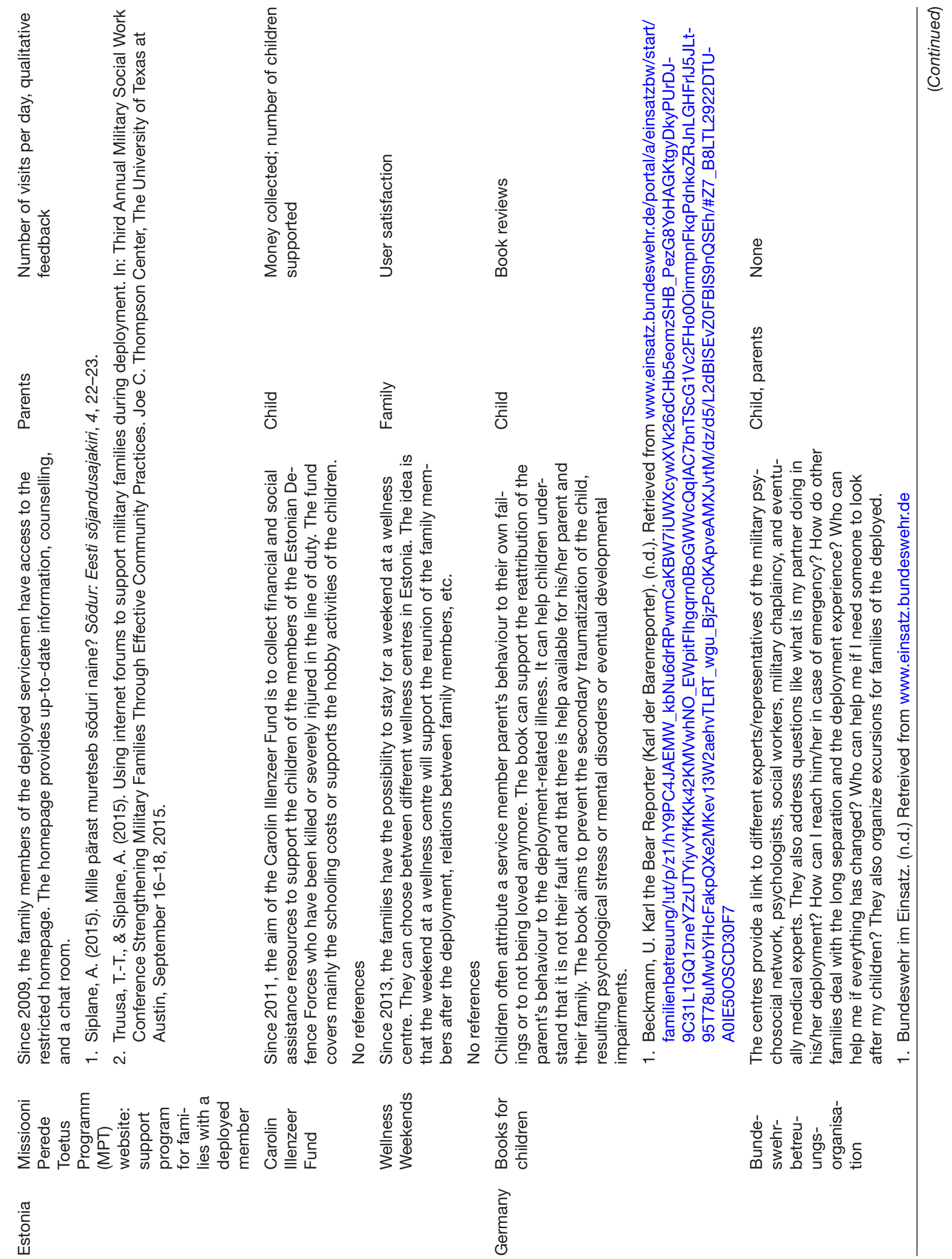




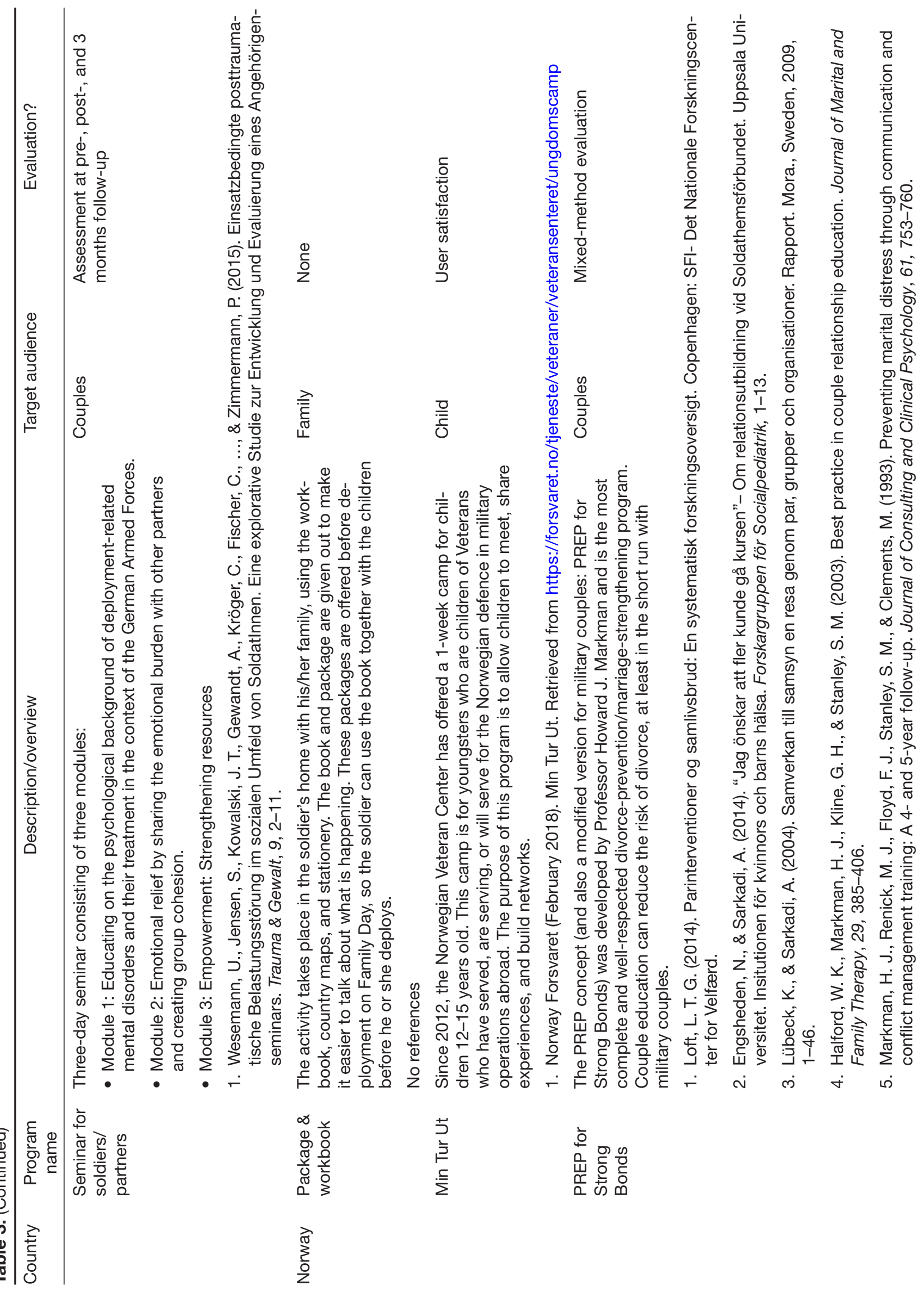




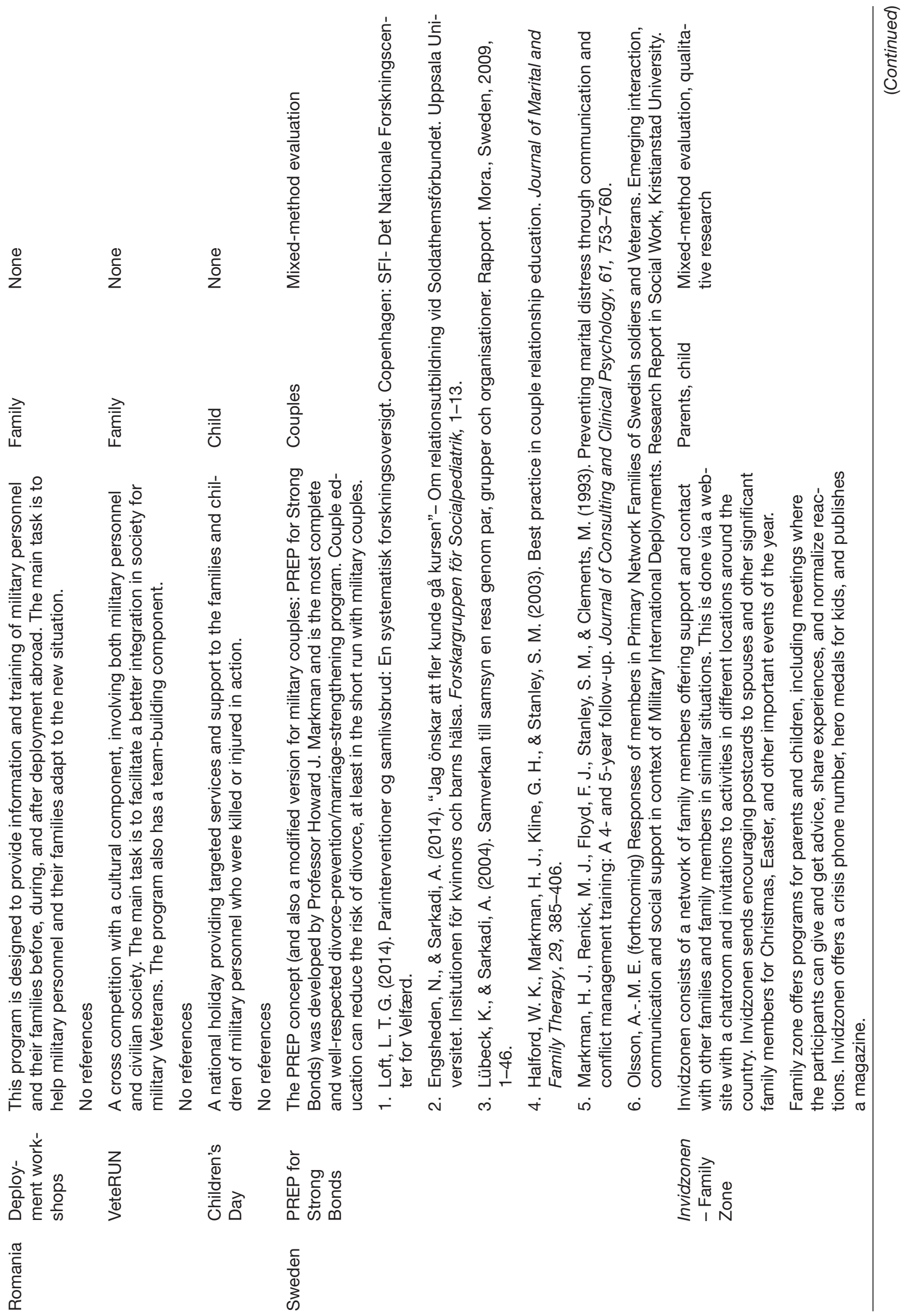




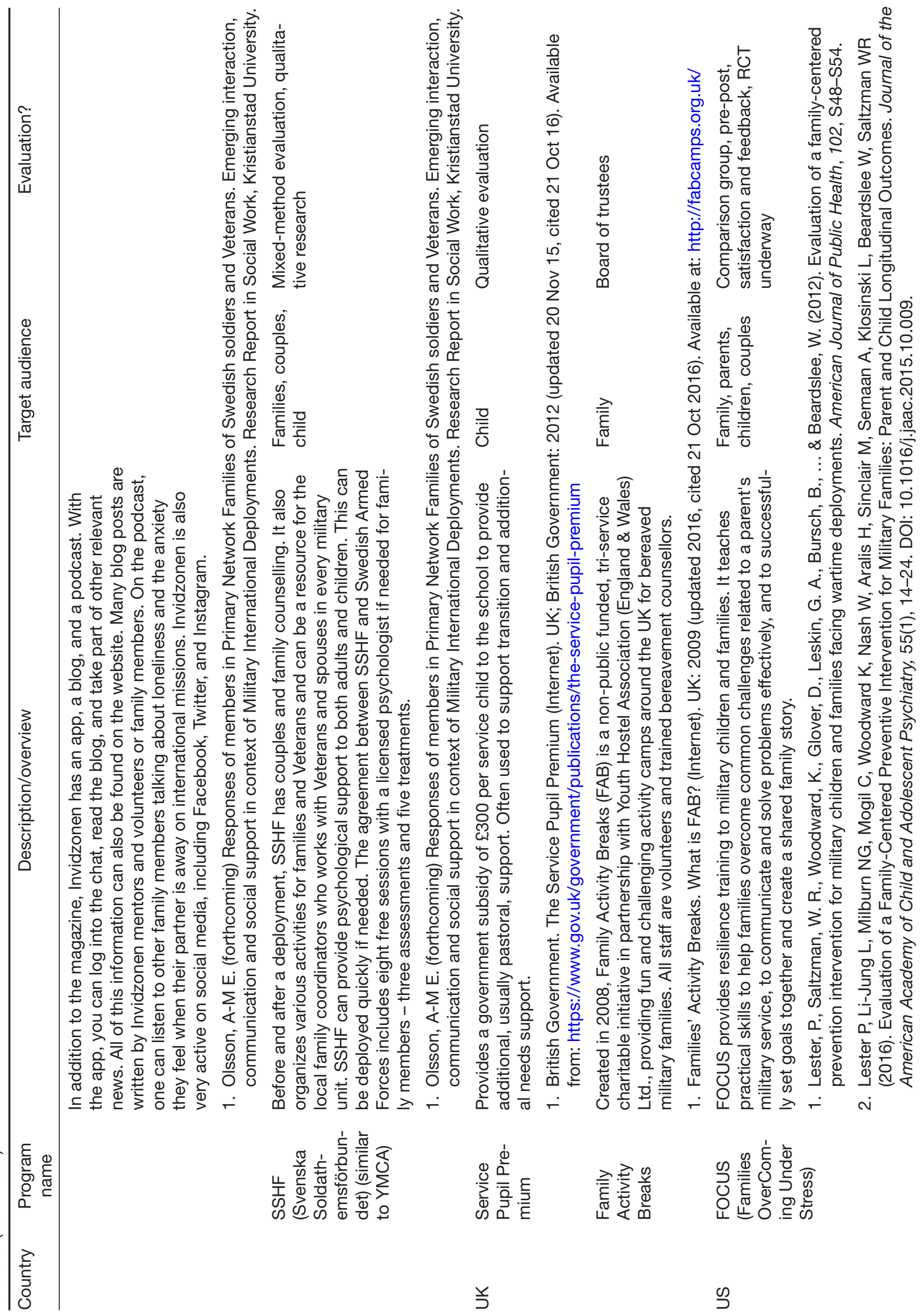




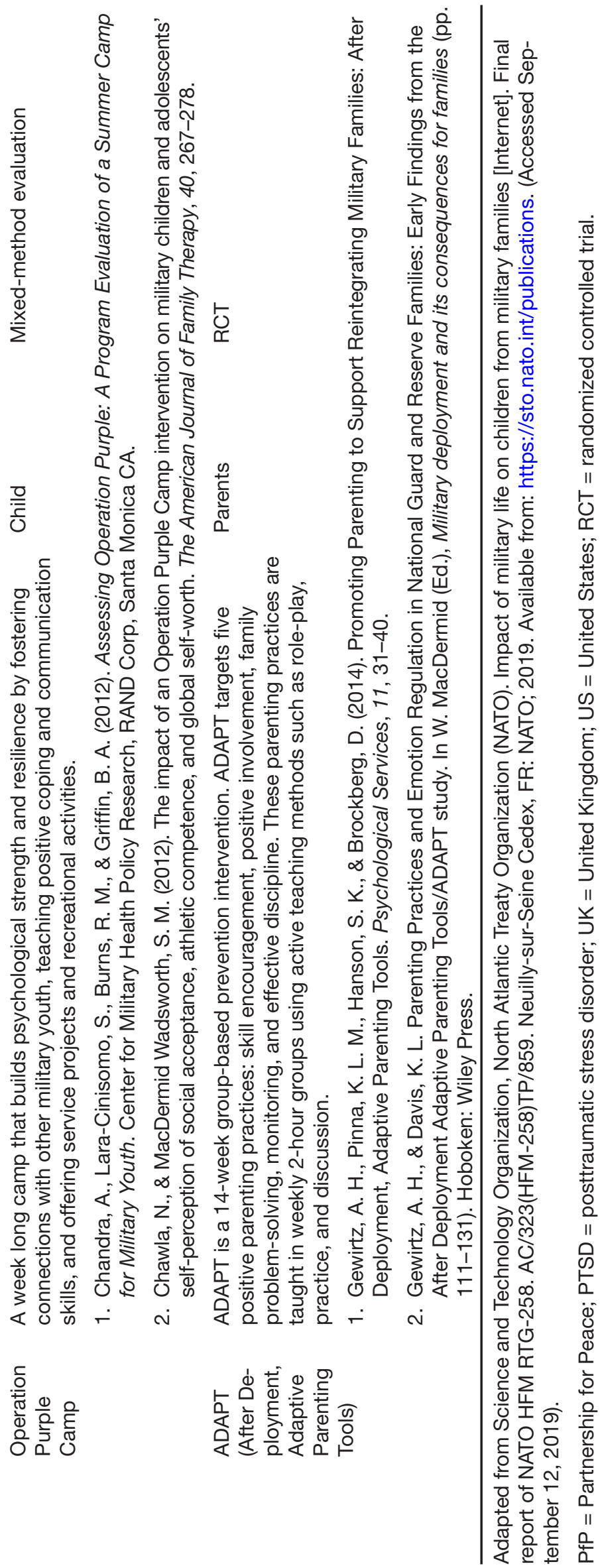


members. In addition, some military families choose to seek support outside the military institution or through programs developed for the civilian population.

\section{Recommendations}

Although many of the programs reviewed had no evaluation data to support efficacy, the programs may be effective for use in military families. When a program appears to have an appropriate cultural fit for military families, and it has positive satisfaction data, it is recommended that the program's efficacy be evaluated in a comparison study. While the gold standard for efficacy trials is a randomized controlled study, this is not always feasible due to the program's content, size, and cost of an efficacy trial. In addition, it might be urgent to begin implementation at scale right away in order to begin serving families in critical need. Government mandates and public pressure may also affect the ability to perform rigorous scientific inquiry prior to program implementation. In 2007, for example, the American Psychological Association released a report documenting the unmet needs of children in military families in the United States. Following its release, there was government and public pressure to implement programming that would better meet the psychological needs of US military families and initiate greater preventive efforts to thwart the wear and tear of multiple deployments. As a result, several programs were rapidly scaled up without the completion of research to determine efficacy. ${ }^{37}$

The use of a comparison group can often achieve immediate delivery of service and research into efficacy in a cost-effective manner. For example, comparing child outcomes for those receiving services with those who are on a waitlist may provide some evidence to support the efficacy of an intervention..$^{38}$ Similarly, comparing those who complete a program with those who do not complete a program is another possibility.

The use of blended quantitative and qualitative methods may also strengthen evidence to support the use of a program, though each of these methods introduces limitations to the interpretation of the results. It can be helpful to perform qualitative evaluation of evidence-based programs that are newly adapted for a cultural context or special population. Qualitative evaluation can provide information that might not be uncovered in a quantitative design and can help fine tune an intervention to further enhance the application and utility within a population. This strategy can be particularly helpful in countries with a small population that may not have a sufficient number of program participants to warrant a costly comparison group and to shed light on helpful practices to support the target group.

As shown in Table 3, several of the reviewed programs have undergone either RCT or a comparison study in other contexts, but have not been evaluated for use in the country in which it is being implemented. When a strong evidence base exists, it may not be necessary to complete an entirely new RCT. However, some adaptation to enhance cultural relevance should always be considered. ${ }^{39}$ This process should start with translating the curriculum into the new language followed by a blind back-translation into the original language to ensure the translation is accurate. ${ }^{40}$ Beyond simply translating the program from one language to another, there is also a need to look at logistical and cultural factors. ${ }^{35}$ For example, a program developed in the United States may include information about multiple deployments, regular changes of duty stations, and the effects on children of moving every 2 years. This information may not be relevant to families of a service member in, for example, Estonia, Sweden, Denmark, or Norway, where families do not tend to move regularly or multiple times as part of military duty. In these countries, the service member may live at home with the family and commute during the week while performing their military duty. The family may therefore be able to stay stationary near to their known and trusted service structures and within close proximity to their networks and circles of support.

Further, countries have different military traditions and histories that affect the general societal attitude toward the military institution and, by implication, military families. This may influence military families' identification with the military and their attitude toward services and programs provided by the military. Program content should be adjusted accordingly. The most agile programs will allow for relatively easy customization to the local context. For example, the FOCUS model consists of five core elements that can be implemented with a variety of family constellations, including single parents and blended families, and adjusted to be responsive to the needs of the family and the system of care within which it is being implemented..$^{41}$ Programs with clearly described core elements - the active ingredients or activities that make a program effective - will be most easily adapted than programs with overly defined or heavily didactic content. ${ }^{42,43} \mathrm{It}$ is also advised that the program evaluators consider using assessment measures 
that have been cross-culturally validated (see Chapter 5 for examples).

Finally, best practice programs provide support to child well-being not just narrowly to the child, but consider the relationship of the child to his or her family, the parent-child relationship, and the child's interaction with other helpful adults through various systems of care (e.g., FOCUS and the Canadian program $\mathrm{E}=\mathrm{MC}$, see Table 3). The importance of using a family or relational approach to intervention not only strengthens the adaptive and coping skills of the child, but also strengthens the network that supports that child. As shown in Table 3, E=MC3 helps develop skills for each family member in order to strengthen the well-being of the overall family. FOCUS provides intervention to the entire family and defines family as whomever the family defines themselves (i.e., it is not based on what the military or state dictates). ${ }^{44}$ This means that other supportive adults who play an important role in care giving can be included in sessions (e.g., a neighbour, a stepparent, a grandparent, or an adult sibling). PTSD Family Coach is another example that provides education and helpful tips to family members and caregivers who provide care and support to a family member with PTSD. ${ }^{45}$ Several programs offer support for the couple relationship or the co-parenting relationship (e.g., PREP, ADAPT) even though the child is not present in sessions. In each of these cases, the focus is on strengthening the relationship through parenting education, communication strategies, or regulating emotions across a relational system. Although some of the above-mentioned programs are not directly targeted at military families, they are based on the assumption that the well-being of military-connected children is affected by the overall function of the family. ${ }^{46}$

\section{Limitations}

One limitation of our approach is that we may have missed some programs that are available to children in military families but are funded through other government programs. At first glance, it appeared that there were fewer military-specific programs in countries labelled as welfare states (e.g., the Scandinavian countries). Upon further examination, we discovered that this might be because so many services are available to the population more generally. It is perhaps overly simplistic to look only at the number of available programs and is important to consider the role of the welfare state because some countries offer a few military-specific programs layered on top of programs to support child and family well-being more generally.

In addition, we found that countries with larger military structures provided several programs not only by the military complex, but also by public-private partnerships, private foundations, and volunteer organizations. To keep track of provided programs, some countries offer a centralized website that provides information and access to various programs. Other countries do not offer a centralized resource and, consequently, the programs may be difficult to find outside of the local context.

Another limitation of this article is that task group representatives tended to provide psychoeducational programs such as the PTSD Family Coach app and Romania's Deployment Workshop. Many of these programs, such as informational websites and books for children, provide education and information but do not offer instrumental ongoing support. It can be difficult to evaluate the impact of these programs on children. Nonetheless, providing access to information is an important part of the service structure for military families. It can be helpful to think of programs across a continuum of care and following a public health approach. Thus, access to information may be all that is needed for some families who can synthesize the information provided and implement suggested strategies on their own without further intervention. Other families may have higher needs and for which information is less likely to be accessed or effective for the family. We recommend that each country offer a variety of programs providing broad information useful for most military families, as well as more targeted strategies for those most at risk for psychological or behavioural challenges.

We designed our initial survey with the goal of identifying programs implemented in each country with an emphasis on programs with at least some evaluation data. This was open-ended and not specifically aligned with our model for child well-being. As a result, we did not receive program descriptions that covered each domain of the model. For example, we did not receive any program within the legal domain. It is possible that most task group representatives do not consider rules and regulations that support child well-being to be programs. For example, Belgium has rules about when a parent can be deployed based on the age of the children within the family. Other countries make similar considerations in deployment decision making. While legal aid may be available in several of the countries, it was not submitted as a program that targets military-connected 
children. Despite this, the task group emphasizes that legal aid, child protection laws, and military regulations that consider the important role of the military parent in child development are critical factors that support child well-being.

\section{Future directions}

As more programs that support the well-being of children in military families are adapted for use in other countries, it will be helpful to develop recommendations for adaptation and implementation. The use of learning collaboratives ${ }^{47}$ may foster sharing of best practices for dissemination in a flexible manner while still upholding fidelity to the core elements of evidence-based models. Originally used in medicine, this model for dissemination brings together multidisciplinary teams from multiple organizations to share lessons learned and useful approaches to engage families, increase system support of evidence-based practices, and enhance innovation. ${ }^{47}$ Teams may meet in person or by phone or webinar format at regular intervals with work periods in between that support the trial of shared practices within each organization.

Research about how families define themselves, what kind of support they prefer to receive, and how and when they would like to receive it may be helpful as we develop and implement programs across cultural contexts, with the different roles of the welfare state and with varying involvement in shifting military operations and contexts. In the United Kingdom, researchers have examined perception of the family by military service members and their dependants. ${ }^{48}$ The results suggest that families do not necessarily follow the common or traditional perception of family as a mom, dad, and two children. Many blended families exist, as well as families with single parents, same-sex parents, or grandparents as primary caregivers. As a result, it may be helpful to broaden the scope to include other caregivers and supportive others such as stepparents, stepsiblings, or extended family members, in programming, even if they do not have the "lived" military experience. In many countries, such as Estonia, there is a very young military force, where some service members are as young as 17 years of age. These service members are often single, but are still members of a family. Services to strengthen their family relationships with adult parents or siblings can still be useful to better support the health and well-being of the service member. This may aid in retention of services members, support force mental fitness, and reduce suicide risk, but also may have longterm positive effects because these young service members may eventually become parents themselves.

\section{Conclusions}

In conclusion, one of the goals of this task group was to identify best practices for programs to support children in military families. Twenty-six programs from nine countries were reviewed to identify best practice programs. Recommendations include the following:

1. Implementation of diverse types of programming to meet the multicultural needs of individual families within a country's military population.

2. Adoption of existing evidence-based interventions.

3. Selection of programs that can be easily adapted to differing cultural contexts and national systems of care.

4. Selection and implementation of programs that focus on strengthening family relationships.

5. Provision of funding for program evaluation.

\section{REFERENCES}

1. Alfano CA, Lau S, Balderas J, et al. The impact of military deployment on children: placing developmental risk in context. Clin Psychol Rev. 2016;43:17-29. https://doi.org/10.1016/j.cpr.2015.11.003. Medline: 26655960

2. Mustillo S, MacDermid Wadsworth S, Lester, P. Parental deployment and well-being in children: results from a new study of military families. J Emot Behav Disord. 2016;24(2):82-91. https://doi. org/10.1177/1063426615598766.

3. Nelson SC, Baker MJ, Weston CG. Impact of military deployment on the development and behavior of children. Pediatr Clin N Am. 2016;63(5):795-811. https://doi.org/10.1016/j.pcl.2016.06.003. Medline:27565359

4. Frasquilho D, de Matos MG, Marques A, et al. Unemployment, parental distress and youth emotional well-being: the moderation roles of parent-youth relationship and financial deprivation. Child Psychiatry Hum Dev. 2016;47(5):751-8. https://doi. org/10.1007/s10578-015-0610-7. Medline:26646144

5. Pfoertner TK, Rathmann K, Elgar FJ, et al. Adolescents' psychological health complaints and the economic recession in late 2007: a multilevel study in 31 countries. Eur J Public Health. 2014;24(6):961-7. https://doi. org/10.1093/eurpub/cku056. Medline:24860027

6. Reiss F. Socioeconomic inequalities and mental health problems in children and adolescents: a systematic review. Soc Sci Med. 2013;90:24-31. https:// 
doi.org/10.1016/j.socscimed.2013.04.026. Medline:23746605

7. National Defence and the Canadian Armed Forces [homepage on the Internet]. Ottawa (ON): Government of Canada; [cited 2017 Dec 18; modified 2018 Sept 04]. Housing. Available from: http://www.forces. gc.ca/en/caf-community-support-services-housing/ index.page.

8. National Defence and the Canadian Armed Forces [homepage on the Internet]. Ottawa (ON): Government of Canada; [cited 2017 Aug 22; modified 2018 Oct 10]. Deployment resources for family members. Available from: http://www.forces.gc.ca/en/cafcommunity-health-services-r2mr-deployment/ deployment-resources-family-members.page.

9. Military One Source. Family \& relationships [homepage on the Internet]. Arlington (VA): United States Department of Defense; c2018 [cited 2019 Aug 28]. Available from: https://www.militaryonesource.mil/ family-relationships.

10. Military One Source. Housing - benefits. [homepage on the Internet]. Arlington (VA): United States Department of Defense; c2017 [cited 2019 Aug 28]. Available from: https://www.militaryonesource.mil/ moving-housing/housing/housing-benefits.

11. UK Ministry of Defence. Support services for military and defence personnel and their families [homepage on the Internet]. London (UK): Government Digital Service; [cited 2017 Sep 25]. Available from: https:// www.gov.uk/topic/defence-armed-forces/supportservices-military-defence-personnel-families.

12. Carter SP, Loew B, Allen ES, et al. Distraction during deployment: marital relationship associations with spillover for deployed army soldiers. Mil Psychol. 2015;27(2):108-14. https://doi.org/10.1037/ mil0000067. Medline:26236093

13. Gewirtz AH, Erbes C, Polusny MA, et al. Supporting military families during and after deployment: the need for parenting interventions. Prof Psychol Res Pr. 2011;42(1):56-62. https://doi.org/10.1037/ a0022345.

14. Greene T, Buchman J, Dandecker C, et al. How communication with families can both help and hinder service members' mental health and occupational effectiveness on deployment. Mil Med. 2010;175(10):745-9. https://doi.org/10.7205/milmed-d-09-00278. Medline:20968264

15. Mulligan K, Jones N, Davies M, et al. Effects of home on the mental health of British forces serving in Iraq and Afghanistan. Br J Psychiatry. 2012;201(3):193-8. https://doi.org/10.1192/bjp.bp.111.097527. Medline:22539778

16. Park N. Military children and families: strengths and challenges during peace and war. Am Psychol.
2011;66(1):65-72. https://doi.org/10.1037/a0021249. Medline:21219050

17. Creech SK, Hadley W, Borsari B. The impact of military deployment and reintegration on children and parenting: a systematic review. Prof Psychol-Res Pr. 2014;45(6):452-64. https://doi.org/10.1037/ a0035055. Medline:25844014

18. Saltzman WR, Lester P, Beardslee WR et al. Mechanisms of risk and resilience in military families: theoretical and empirical basis of a family-focused resilience enhancement program. Clin Child Fam Psychol Rev. 2011;14(3):213-30. https://doi.org/10.1007/s10567011-0096-1. Medline:21655938

19. De Pedro KM, Astor RA, Benbenishty R, et al. The children of military service members: challenges, supports, and future educational research. Rev Educ Res. 2011;81(4):566-18. https://doi. org/10.3102/0034654311423537.

20. Norris D, Cramm H, Eichler M, et al. Operational stress injury: the impact on family mental health and wellbeing [report]. Ottawa (ON): Veterans Affairs Canada; 2015.

21. Andres MD. Behind family lines: family members' adaptations to military-induced separations [dissertation]. Tilburg(NL): Tilburg University; 2010.

22. Boričević Maršanić V, Aukst Margetić B, Jukić V, et al. Self-reported emotional and behavioral symptoms, parent-adolescent bonding and family functioning in clinically referred adolescent offspring of Croatian PTSD war Veterans. Eur Child Adolesc Psychiatry. 2014;23(5):295-306. https://doi.org/10.1007/s00787013-0462-2. Medline:23949102

23. Kudler H, Porter RI. Building communities of care for military children and families. Future Child. 2013;23(2):163-85. https://doi.org/10.1353/ foc.2013.0019. Medline:25518697

24. Lester P, Liang LJ, Milburn N, et al. Evaluation of a family-centered preventive intervention for military families: parent and child longitudinal outcomes. J Am Acad Child Adolesc Psychiatry. 2016;55(1):14-24. https://doi.org/10.1016/j.jaac.2015.10.009. Medline:26703905

25. DeVoe ER, Ross AM. Engaging and retaining National Guard/Reserve families with very young children in treatment: the Strong Families Strong Forces Program [Internet]. Washington, DC: American Psychological Association. 2013 Jun [cited 2018 Oct 10]. Available from: http://www.apa.org/pi/families/resources/ newsletter/2013/01/strong-families.aspx.

26. Wolf MR, Eliseo-Arras RK, Brenner M, et al. "This will help your children”: service providers' experiences with military families during cycles of deployment. J Fam Soc Work. 2017;20(1):26-40. https://doi.org/10.1080/10 522158.2016 .1259135 . 
27. Gewirtz AH, Pinna KL, Hanson SK, et al. Promoting parenting to support reintegrating military families: after deployment, adaptive parenting tools. Psychol Serv. 2014;11(1):31-40. https://doi.org/10.1037/a0034134. Medline:24564441

28. Wilson SR, Wilkum K, Chernichky SM, et al. Passport toward success: description and evaluation of a program designed to help children and families reconnect after a military deployment. J Appl Commun Res. 2011;39(3):22349. https://doi.org/10.1080/00909882.2011.585399.

29. Markman HJ, Ritchie LL. Couples relationship education and couples therapy: healthy marriage or strange bedfellows? Fam Process. 2015;54(4):655-71. https:// doi.org/10.1111/famp.12191. Medline:26547902

30. Gewirtz AH, Youssef AM. Conclusion and a research agenda for parenting in military families. In: Gewirtz AH, Youssef AM, editors. Parenting and children's resilience in military families. Switzerland: Springer International Publishing; 2016. p. 299-306.

31. Cozza SJ, Lerner RM. Military children and families: introducing the issue. Future Child. 2013;23(2):3-11. https://doi.org/10.1353/foc.2013.0016. Medline:25518689

32. Kamerman SB, Kahn AJ. Home health visiting in Europe. Future Child. 1993;3(3):39-52. https://doi. org/10.2307/1602542.

33. Military OneSource. The new parent support program [Internet]. Washington, DC: U.S Department of Defense; c2017 [updated 2019 Jan 4; cited 2017 Sept 25]. Available from: http://www.militaryonesource.mil/ web/mos/-/the-new-parent-support-program? inheritRedirect $=$ true\&redirect $=\% 2$ Fparentinginfants-and-toddlers.

34. Nordic Co-Operation [Internet]. Copenhagen: Nordic Council; c2017 [cited 2017 June 29]. Hello Norden. Available from: http://www.norden.org/en/hellonorden $/$ nordenfordig ? categories $=\&$ country $=$ sweden .

35. Castro FG, Barrera M, Martinez CR. The cultural adaptation of prevention interventions: resolving tensions between fidelity and fit. Prev Sci. 2004;5(1):41-5. https://doi.org/10.1023/b:prev.0000013980.12412.cd. Medline: 15058911

36. Pollmann JB, Gjelstrup JW, Vedtofte MS. Samtalegrupper for børn og unge-en procesevaluering [report on the Internet]. Ringsted, DNK: Veterancentret 2016 [cited 2018 Oct 10]. Available from: http://www.forsknings databasen.dk/en/catalog/2345661333. Danish.

37. Johnson SJ, Sherman MD, Hoffman JS, et al. The psychological needs of US military service members and their families: a preliminary report. Washington (DC): American Psychological Association; 2007.

38. Creswell JW, Creswell JD. Research design: qualitative, quantitative, and mixed methods approaches. Los Angeles (CA): Sage Publications; 2017.
39. Kumpfer KL, Alvarado R, Smith P, et al. Cultural sensitivity and adaptation in family-based prevention interventions. Prev Sci. 2002;3(3):241-6. Medline: 12387558

40. Ware JE, Keller SD, Gandek B, et al. Evaluating translations of health status questionnaires: methods from the IQOLA project. Int J Technol Assess Health Care. 1995;11(3):525-51. https://doi.org/10.1017/ s0266462300008710. Medline:7591551

41. Beardslee W, Klosinski L, Saltzman W, et al. Dissemination of family-centered prevention for military and Veteran families: adaptations and adoption within community and military systems of care. Clin Child Fam Psychol Rev. 2013;16(4):394-409. https://doi. org/10.1007/s10567-013-0154-y. Medline:24129478

42. Kegeles SM, Rebchook GM, Hays RB, et al. From science to application: the development of an intervention package. AIDS Educ Prev. 2000;12(5 Suppl):62-74. Medline: 11063070

43. Kelly JA, Heckman TG, Stevenson LY, et al. Transfer of research-based HIV prevention interventions to community service providers: fidelity and adaptation. AIDS Educ Prev. 2000;12(5 Suppl):87-98. Medline: 11063072

44. Mogil C, Hajal N, Garcia E, et al. FOCUS for early childhood: a virtual home visiting program for military families with young children. Contemp Fam Ther. 2015;37(3):199-208. https://doi.org/10.1007/s10591015-9327-9. Medline:26543320

45. U.S. Department of Veterans Affairs. PTSD: National Center for PTSD [homepage on the Internet]. Washington: U.S. Department of Veterans Affairs; c2014-2018 [cited 2017 May 31; updated 2019 Jul 1]. Available from: https://www.ptsd.va.gov/index.asp.

46. Wadsworth SM, Hughes-Kirchubel L, Riggs DS. Research and training about military families: where are we? In: Wadsworth SM, Hughes-Kirchubel L, Riggs DS, editors. Military deployment and its consequences for families. New York: Springer Science+Business Media; 2014. p. 1-17.

47. Ebert L, Amaya-Jackson L, Markiewicz J, et al. Development and application of the NCCTS learning collaborative model for the implementation of evidence-based child trauma treatment. In: McHugh RK, Barlow $\mathrm{DH}$, editors. Dissemination and implementation of evidence-based psychological interventions. New York: Oxford University Press; 2002. p. 97-123.

48. Keeling M, Wessely S, Fear NT. Marital status distribution of the U.K. military: does it differ from the general population? Mil Behav Health. 2017;5(1):26-34. https://doi.org/10.1080/21635781.2016.1213210.

\section{AUTHOR INFORMATION}

Catherine Mogil, PsyD, is an Associate Clinical Professor at the University of California Los Angeles. Her research 
focuses on developing interventions to better serve families facing adversity, including military-connected children, medically-fragile infants, and families involved in the childwelfare system. She is the co-developer of a resilience-building intervention for military families (FOCUS) and a subject matter expert for several US military service organizations.

Maj Hedgegaard Heiselberg, $\mathrm{PhD}$, has focused her research around family life, parenthood, and gender in Danish families going through military deployment. Maj has published her work in (among other places) the journals Critical Military Studies and Gender, Place \& Culture. During her PhD studies in Anthropology, Maj was also a member of the NATO task group "Impact of Military Life on Children from Military Families”.

Allison Clement, MPH, is a Program Manager at the University of California Los Angeles Division of Population Behavioral Health. Her research interests include health promotion and wellness for military families and LGBTQ+ populations.

Anni B.S. Nielsen, PhD, MSc Political Science, RN, is senior researcher at the Research and Knowledge Centre in the Danish Veteran Centre. Her research experience includes longitudinal cohort-studies of health-related outcomes in different populations. Her current research focuses on health and social function of children, partners of military personnel, and longitudinal studies on Veterans.

\section{COMPETING INTERESTS}

Catherine Mogil is the co-developer for the FOCUS program that is described in this article.

This article has been peer reviewed.

\section{CONTRIBUTORS}

Catherine Mogil, Maj Hedgegaard Heiselberg, and Anni Brit Sternhagen Nielsen helped select the research questions and data set, analyzed the results, and drafted the manuscript. Allison Clement conducted the survey, collected data, analyzed results, and edited and revised the manuscript. All authors approved the final version submitted for publication.

\section{FUNDING}

None declared. 